\title{
From Casamance to Turin. Lao Kouyate's Modern Travelling Griot
}

The Creation of a Space for Discursive Mobility

"Le griot moderne nomade " de la Casamance à Turin. La création d'un espace

de mobilité du discours

\section{Giulia Pizzolato}

\section{(2) OpenEdition}

\section{Journals}

Electronic version

URL: http://journals.openedition.org/etudesafricaines/17732

DOI: 10.4000/etudesafricaines. 17732

ISSN: $1777-5353$

\section{Publisher}

Éditions de l'EHESS

\section{Printed version}

Date of publication: 30 June 2014

Number of pages: $475-498$

ISSN: 0008-0055

\section{Electronic reference}

Giulia Pizzolato, «From Casamance to Turin. Lao Kouyate's Modern Travelling Griot », Cahiers d'études africaines [Online], 213-214 | 2014, Online since 27 June 2016, connection on 20 April 2019. URL : http://journals.openedition.org/etudesafricaines/17732; DOI : 10.4000/etudesafricaines.17732

This text was automatically generated on 20 April 2019.

(C) Cahiers d'Études africaines 


\title{
From Casamance to Turin. Lao Kouyate's Modern Travelling Griot
}

\author{
The Creation of a Space for Discursive Mobility \\ "Le griot moderne nomade " de la Casamance à Turin. La création d'un espace \\ de mobilité du discours
}

Giulia Pizzolato

1 This article focuses on an essential aspect of migration that is entextualization as a process of discursive mobility associated with displacement and as a representation of it. The notion of "entextualization" dates back to Bauman and Briggs' article (1990), which inspired the analysis here presented. As the American authors explain, "entextualization" refers to the process of "decontextualization and recontextualization" of a text, and it has significant implications in social life ${ }^{1}$. According to this idea, in this article the concept of entextualization is analysed within the more general framework of the migratory phenomenon: the analysis focuses on the language productions of Lao, a young Senegalese living in Turin (Italy) ${ }^{2}$.

2 At the time of my fieldwork, Lao had been living in Turin for several months and in Italy for about two years. He was married to an Italian woman and they had a baby. They had moved from Rome to Turin, looking for a city that could benefit Lao's career as a musician. Lao's self definition as a "travelling modern griot" made him a particularly suitable candidate to support the thesis I will try to defend in this article. Lao comes from a family of griots in the region of Casamance in southern Senegal and his language productions considered in this paper are explicitly and representatively a "griot's discourse" 3 . He gives an account of himself as a sort of expatriated griot who aims at translating and creating the conditions for discursive (thus social too) action beyond those areas that he defines as characterizing the tradition of "griottisme". The analysis will focus on Lao's discursive productions collected during the performances called "stasera maffe" on, these evenings consist in a Senegalese dinner followed by Lao performing as a musician and a storyteller. As a matter of fact, the audience, mainly composed of friends 
or acquaintances of Lao and his wife, was not aware of the programme of each "stasera maffe" ${ }^{\prime}$ event. It was only after dinner that the guests would discover that Lao's presentation was not just about music ${ }^{6}$ but also a narrative performance, referring to a West African centuries-old tradition. Therefore, through Lao's performance, the audience would learn about the griot and his social function in Senegal, a country the invitees often barely knew by name.

Lao's discursive productions are considered in this paper as actions performed within a particular frame and, most of all, linked to meaning-generating social practices (Bourdieu 1977). Therefore, language and the dialogic production of discourse (Bakhtin 1977) concur in elaborating and representing the existing logics and social practices. This happens on three levels of different natures: a. social; b. inter-personal; c. subjective.

Discourse accomplishes such representations/elaborations in the three following ways:

1. by representing current imageries and ideologies (a.);

2. by displaying hierarchies and, generally, power relationships between individuals (b.);

3. by telling something about the subject (speaker), about his history and his migratory course (within and in relation to $a$. and b. levels).

Discourse acts through content, but most of all through formal features which are rich of ideological significances that have an impact on social life: lexical or stylistic elements or ways of speaking. In my examination, I would like to emphasize the connection between these dynamics and those which pertain migration-a process multiplying links between different times-spaces and individuals-their point of intersection being entextualization itself.

6 Such process actually represents a replication of discourse ${ }^{7}$, and so a recontextualization, which not only connects a "preceding discourse" with its "copy" (Urban 1996), but also the different interlocutors and instances uttering them, as I am going to examine in the following paragraph.

7 This article attempts to analyse the strategies of a migrant's social repositioning through the analysis of Lao's discursive productions. I argue that the interpretation of the griot's discursive productions in a migratory context ${ }^{8}$ and the analysis of repositioning strategies of such discourses in an "other" context (Italy), tells us a lot about the circulation of discourse and individuals, about their value and impact on society.

8 A special attention will be paid to meta-performative elements which are used to create and define a discursive space, such as the one we have seen in MEs, during which Lao performs. I will show that the meta-performative level represents a strategy for Lao for him to be able to justify, construct and implement the recontextualization of his "griot's discourse".

9 By analysing the process of entextualization the young Senegalese migrant carries out, I will be able to observe what of a "griot's discourse" and its history is "transferred" into the MEs (Blommaert 1999) ${ }^{9}$ and for what social purposes: What are the meanings and values of this process in social terms? How are the construction and the transformation of such "griot's discourse" fulfilled, given that this process interacts both with its history ${ }^{10}$ and with the context of enunciation (MEs but also migratory and Italian context)?

As Duchêne (2009: 136) suggests, observing and analysing such process of discourse transformation may tell a lot about the social changes that the migratory phenomenon brings along: 
"Le discours (quel que soit d'ailleurs son support) est le locus de la fabrication de l'histoire et du changement. En effet, tout événement, toute expérience, tout souvenir, se matérialisent - et sont donc socialement rendus accessibles - par la médiation du discours. L'histoire en tant que discipline n'existerait pas sans le passage par le discours, et les changements sociaux deviennent perceptibles et préhensibles par leur matérialisation dans le discours."

\section{Entextualization and Migration}

What I propose in this article is based on the combination of two elements: language and mobility. The concept of discourse underlying Bakhtinian "dialogism" (Bakhtin 1977), chosen here as a theoretical basis, as an act interconnected to and interconnecting discourses located elsewhere in space and time, shares common points with the concept of "circulatory territories" (Tarrius 2002), on which transnational studies are based. Paraphrasing Silverstein and Urban (1996), the focus here is on the process of transmission of discourse through the time spread-space of migrants and migration. This is the way the notion of entextualization-as a process of discourse circulation (basis of Bakhtin's theory) acquires a key role. Although the classic definition of entextualization by Bauman and Briggs (1990: 73) mainly refers to poetic performances, it can easily be applied to a wider range of discursive productions. Here is the definition:

"At the heart of the process of decentering discourse is the more fundamental process-entextualization. In simple term, though it is far from simple, it is the process of rendering discourse extractable, of making a stretch of linguistic production into a unit-a text-that can be lifted out of its interactional setting. A text, then, from this vantage point, is discourse rendered decontextualizable. Entextualization may well incorporate aspects of context, such that the resultant text carries elements of its history of use within it. Basic to the process of entextualization is the reflexive capacity of discourse, the capacity it shares with all systems of signification to turn or bend back upon itself, to become an object to itself, to refer to itself ${ }^{11}$. In Jakobsonian terms, with regard to language, this reflexive capacity is manifested most directly in the metalingual and poetic functions."

12 The crucial point, in the perspective here proposed, is not the process by which a discourse "detaches itself" from its context of production in order to relocating in a new social context, but rather the relationship developing between different discourses, between discourse and its author, between speakers (author-author) and between the speaker and the context, in a dialogical conception of discursive productions.

What is therefore relevant here to consider is what in a given discourse and its relative history is "transported"; how the discourse is constructed and transformed; the meanings and values it acquires in social life.

Entextualization is then thus to be considered from under two main perspectives, which correspond to two moments and two aspects of the same process. The first is closer to the Bauman and Briggs' definition and it refers to the "creation" of a discourse by the migrant, who enacts a de-contextualisation in order to accomplish a re-contextualisation of discourse. In the second perspective, the notion refers to the reproduction of a given discourse, and therefore to the ways, the purposes and the dynamics in which it occurs and to which it responds to. 

"other" than that of origin ${ }^{13}$. Examining contextualization and textualization (i.e. the process of replication), rather than context and text, as Bauman and Briggs suggest, allows to focus on the agency of interlocutors (Lao and his audience) and therefore on the social relevance of the discursive event. Therefore I will concentrate on the discursive and meta-discursive strategies Lao elaborates to reproduce and legitimize the function of both his "griot's discourse" and his "modern travelling griot" in front of his audience. Such strategies refer on one hand to an allegedly "griot tradition" of which Lao becomes a sort of purveyor for his audience, on the other hand, they have to a personal and unique way for Lao to be a griot. These two somehow opposite dynamics trace the profile of Lao's migration.

\section{The "stasera maffe" Evenings}

"Stasera maffe!" is the name Lao and his partner Eleonora have given to the evenings of Senegalese cuisine and music taking place at their house. When we met, the young couple had recently moved to Turin and was trying to settle in a city they barely knew. They lived in an apartment not completely furnished yet; they were looking for a job and trying to gradually build a network of social relations, as well as useful contacts for Lao's artistic career ${ }^{14}$. MEs became an opportunity to fulfill all these aspirations. The evenings included two main features: the dinner, during which maafe ${ }^{15}$ was served, and Lao's music/story telling performance. In this second part, the young Senegalese played songs from his repertoire, interleaving them with tales or descriptions ${ }^{16}$. The number of guests was always limited ${ }^{17}$, also due to the modest size of the apartment. arrangement, the construction of Lao's "character" and the role assigned to and played 
by the guests. As for Lao in particular, it is important to know that he always wore traditional Senegalese clothing: colorful boubous and slippers, which was quite unusual for him who normally wore "western clothes". The apartment, in turn, was decked out the "African way" for the occasion: batik fabrics on the walls, masks and crafts from Senegal. These aspects can be interpreted on the basis of two fundamental features of "Stasera maffe!" as a discursive space: exoticism on one side, and the tension between modernity and tradition on the other. There are indeed the two elements around which Lao's performance is conceived. Exoticism refers both to Lao as a character and to the MEs in itself. Its main purpose was to create a distance between the event and the audience ${ }^{18}$ as well as to provide the event with a sort of frame, but several other aspects arise from it. Firstly, a spectacularisation of Lao's performance and of his act of discourse; secondly, and consequently, the audience attention focuses on his person, thus his experience and his role as a griot from birth and musician are enhanced. When Lao turns into the true and only star of the evening, even by means of scenic elements that separate him from his audience, the expectations and the curiosity of the observer are amplified, facilitating the construction of his character and performance. The guests, often Lao and Eleonora's friends and acquaintances, were always unaware of how MES would unfold: they were simply attracted by the exoticism of an event presented by the hosts as "a Senegalese evening with food and music". They were therefore joining in for the sake of approaching "another culture"-"the Senegalese one", or "the African one". What is more, not only they ignored the development and dynamics of the MEs event, but also most of them knew nothing about Africa, nor Senegal, let alone "griottisme".

21 For what concerns the combination of tradition and modernity, it is a rather complex aspect, which goes beyond scenic aspects. The whole MEs event is in fact characterized by a constant dialogue between "tradition" and "modernity": Lao refers to it in his discourse and in his music ${ }^{19}$ as the whole event ${ }^{20}$. Lao often swings back and forth between the poles of this dualism which also implies a dichotomy between Africa and the West depending on different purposes of his discourse: if on the one hand the tradition legitimizes the griot's performance ${ }^{21}$ and justifies his movements and his discourse, on the other hand modernity allows Lao to approach and share the "universe of discourse" (Levelt 1989) of the audience. The element of modernity thus turns Lao into a mediator between his audience and the assumed "traditional repertoire" he draws from and performs.

In other words Lao carries out a double process of ideological essentialization and of a differentiation. The first process uniforms a presumed "griot's discourse"-and thereby griots themselves-elaborating a sort of "griot discourse" stereotyped as to constitute a tradition of reference. This process seems to correspond to "the process of rendering discourse extractable, of making a stretch of linguistic production into a unit-a textthat can be lifted out of its interactional setting" as Bauman and Briggs (1990: 73) claim. Lao finds there legitimacy for his stage-set of MEs and for an appropriation of that "espace de discours" ("discursive space"). The second process contrasts such tradition and the group of "the other griots" in order to build himself as a "modern griot" able to renew a consolidated and almost outdated repertoire and to adapt the contents of his linguistic performance to a shared universe of discourse ${ }^{22}$. Such adaptations are the result of a natural gift and of a story of migration, which Lao has been able to profit from. Indeed, his migratory experience put him in touch with different realities, "different worlds" and contexts to which his performance had to adapt ${ }^{23}$. 
23 In the following paragraphs I am going to show how this double process of essentialization/differentiation linked to the dualism modernity/tradition undergoes development through three main discourses recurring in his MEs repertoire:

1. Legitimization of Lao's role and discourse with reference to the tradition of "griottisme";

2. Modernization of the role of a griot in West African societies;

3. Subjectification of the function of the griot.

24 Our analysis will especially tackle the second phase of the MEs that is the narrativedescriptive after-dinner by focusing on the construction of the discursive event. As we consider it an espace de discours recurring and constant elements can be found though in the context of an occasional event like MEs each time requiring adaptations to the audience. The analysis and the interpretation of these particular discursive productions are evidently also influenced by our observations of Lao outside MEs, in his daily life over several months which provided us with the background to interpret Lao's role in the MEs.

\section{The Creation of an "espace de discours"}

Analyzing Lao's performances during the MEs, means focusing on his process of construction and acquisition of an espace de discours. The development of MEs has been observed as the creation of a discursive repertoire that has gradually become the script for a show. Lao was performing as a musician and storyteller but his music-narration performance has also become a way of "staging the self". The progression of MEs creates an actual ritual, which, on the one hand, look up to an alleged "tradition"-the "griottisme"-while on the other is based on the circumstantial necessities of the MEs as a discursive event.

Here, I intend to focus on the construction of the "performance" in its ritualistic dimension by emphasizing the "meta-performative" elements, which serve the management of the exhibition. These include épilinguistique (Canut 2000) and metadiscursive elements (anaphoric references to the text or the conversation, autonyms, corrections), as well as proper meta-performative elements (explicit references to what Lao is doing, engaging with the audience and reference to its universe of discourse [Levelt 1989], introductions to or translations of the musical interludes). The fundamental aspect of Lao's language productions during the MEs in our perspective is not so much what it is said but rather the fact that it is "the performance of a griot", an aspect he moreover emphasizes by situating on different levels (i.e. intra-discursive, metadiscursive, meta-performative).

I shall now examine how Lao stages his performance and his "griot's character". The process is implemented by means of an implicit and an explicit strategy. The former consists of all "griot-like" actions and references which Lao enacts without justifying them and taking them for granted, assuming they belong to his audience's universe of discourse. This strategy is evident in the preparation of the performance on a symbolic level: Lao's clothing, the arrangement of the audience and the musician, the way he takes the floor ${ }^{24}$. Often the audience does not fully cooperate: being unaware of the role of a griot and of "griottisme" in West African societies it appears puzzled, disoriented and distant, as if attending a "socio-linguistic ritual" (Charaudeau \& Maingueneau 2002) ${ }^{25}$ it does not know. The guests-at least at first-seem uneasy, confused, often do not 
respond adequately to Lao's inputs, they fail to be an active part of the show and of the communicative exchange. For these reasons, this implicit component in Lao's construction of the griot-performance has progressively been reduced over the MEs, as he gradually adapted the show to his audience. The storyteller then devoted more space to the explicit construction of his performance and role. This was achieved through three main steps, corresponding to three discourses:

Discourse 1. Validation of his role and his discourse with reference to the tradition of "griottisme", i.e. through History;

Discourse 2. Modernization of the role of griots in West African societies;

Discourse 3. Subjectification of the griot's function.

While discourses 1 and 2 are likely to help the audience share those defining characteristics of the griot and its social meaning in West Africa, both today and in the past, in a timeless tradition; discourse 3 focuses on Lao's personal experience.

Let's examine some examples.

Discourse 1.

(1.1)

${ }^{26} \mathrm{~L}$ : quindi em+è questo mio nome è Lao+sono senegalese $+e$ vive in Italia a Torino da poco tempo +/sono griot/+a+per (incomprensibile) vuol dire cantastorie e+mestiere che fa (incomprensibile) non so (incomprensibile) miei genitori e anche non genitori lo fanno

D:!ah!

L: e sono nato di questa famiglia+noi siamo un uno o+ non si dice etnia?no?

E: sì

L: un'etnia e i griot è sempre vicino a+ il re+perché quei tempi non c'erano scritture in Africa +quindi e+ questo griot che

E: trasmetteva

L: trasmetteva generazione in generazione quello che è successo

F:\%con la musica mm\%

L: con la musica+e+e quello che è griot+e poi c'è questi pezzi che sono in e+è nostra parte del mondo questa etnie che si chiama mande e quelli pezzi sta suonando e poi adesso c'è altri generi anche sempre nella base della musica mande perché loro conosce perché

F: (incomprensibile)

L: voi no voi magari in futuro dovete anche sapere ALLORA QUELLO GRIOT è sempre vicino al re prendiamo anche dove eravamo in punto+memorizzavo+perché l'importanza era griot che!il re! non può andare dire "io sono questo sono questo"+sempre c'è il griot che deve promuovere il re che deve dire creare $i$ pezzi e+questo impero del mande è nato questi strumenti+e kora e (incomprensibile) recemmente però è nato prima questo instrument (...) eh tutto ̀̀

[L $\mathrm{L}^{27}$ : so emm/this is my name is Lao/ I'm Senegalese/and I have moved to Italy, in Turin, recently / I'm a griot/ a/ for (inaudible)/ it means storyteller and/ it's the profession of (inaudible) I don't know (inaudible)/ of my parents and who are not parents too

$\mathrm{D}^{28}$ : ah!

L: and I was born in this family/ we are a /an or/ we say "ethnic group"/ isn't it?

$\mathrm{E}^{29}:$ yes

L: an ethnic group and griots is always near the king/ because at those times in Africa there wasn't the written tradition/so it's such griot that

E: handed down

L: that handed down from generation to generation what is happened

$\mathrm{F}^{30}$ : \%with music mm\%

L: with music and/ and/ with what griot is/ and then there are these pieces which are in/ this ethnic group called Mande and these pieces I'm playing they are in this side of the world and than now there are other genres ${ }^{31}$ and they are always based 
on the Mande music because they know because

F: (inaudible)

L: you don't/ you maybe in the future you have to know also/WELL THIS GRIOT is always near the king (inaudible) /I memorized/ because what was important is the griot that/ the king can't go and say "I am so and so"/ there is always the griot that has to promote the king that has to speak and create pieces and/ these instruments were created (in) this Mande empire/ and kora ${ }^{32}$ recently but this instrument was born earlier (...) and everything is natural]

(1.2)

L: Gambia tutti erano i paesi di un un altro regno è nato del mande però si dice mandingo (incomprensibile)++si si chiama quello è+!e lì kora è nato!+immagina+ kora non è nato Mali +kora è+perché anche quando vieni costruzione perché è uno strumento che!è dopo i balafon! +perché e+ vedi come la linea è fatta è una cosa avanzata quindi non è anticamente come il tempo di Mali+il tempo di Mali+quando hanno fatto (incomprensibile) Kouyate mio nonno ha suonato il il castello di balafon+ balafon grosso come castello+non+?sai balafon?

El: \% xilofono\%

L: !come xilofono! ma in legno+!castello! +e lì solo a suonare questo+poi legno ma sai primi uomini+!davvero sono forti mamma mia da paura!+legno pesa come djembé (ride)+per un braccio è forte+ e perciò l'hanno nomato Balafassi Kouyate noi veniamo da questo dessandante

[L: they were all countries of another kingdom/ Gambia was born in the Mande but it is said mandingo (inaudible)/ its name is mandingo and that is/ and kora was born there/ imagine/ kora was not born in Mali/ kora is/ because it is an instrument that is after balafon / because it's/ do you see how this line is made/ it is an advanced thing so historically it's not like in Mali's times/ Mali's times/ when they made (inaudible) my grandfather Kouyate played the balafon castle ${ }^{33}$ / balafon is big as a castel /not/ do you know balafon?

$\mathrm{El}^{34}$ : xylophone

L: like xylophone! but timber wood/ castle! /he's there alone to play this / and also wood but you now the first men/ they are really powerful mamma mia! /the wood is as heavy as a as djembé (laughter) / with an arm ${ }^{35}$ he's powerful! / and so they called him Balafassi Kouyate we came from this descendant]

(1.3)

L: questo instrumento+ è primo instrumento di!griot!+griot on+appelle+de ( incomprensibile) che si canta storie+allora+cantastorie oggi si volete quello che giornalismo++in Africa i primi tempi prima che c'è scritture+i griot quello che fanno i re loro non si scrivono li memorizza in parole e ritmi o suonando e questi instrumenti sono instrumenti di griot+però instrumenti sono sempre vicini ai re ( incomprensibile) sai artigianali quando immagina quanti secoli che prima che l'Italia si nascono perché quando li vedi è stessa cosa come la chitarra+la chitarra è industrializzato+ questo è!originale! sai...

[L: this instrument / is the first instrument of the griot/ we call griot (inaudible)/ who sings stories / so/ the storyteller if you want is journalism/ in Africa at first times before written tradition/griots don't write what kings do they memorize it in words and rhythms or playing and these instruments are griot's instruments/but instruments are always near the king (inaudible) you know handmade/ when/ imagine how many centuries before Italy they were born because when you see them they are the same of a guitar/the guitar is industrial / this is original! You know...].

The beginning of Lao's performance takes up a diffuse practice in the African griot performance, which consists in recalling the "griottisme" tradition and explaining his social function, in order to introduce the speaker and affirm his status and his role. In Lao's words the presentation of the role of a griot is conveyed by the name Kouyate ${ }^{36}$ in the first place. Hence his description of what he defines as a "storyteller" or a "journalist": as a matter of fact he insists on the transmission of knowledge ${ }^{37}$, and 
specifically the transmission of the "word of authority"38, through words. In the dualism tradition/modernity this discourse is placed on the "tradition side" because of what I have just pointed out, but also for it refers to History and to a series of elements that bring back to an idea of Africa as "cradle of humanity" ${ }^{39}$ : allusions to "naturalness" as opposed to anything "industrialised", to "originality"-conceived as "authenticity" and "primordially" 40 - to "oral tradition" 41 , and all in all to History validating his discourse just on the basis of its distance and because it's centuries-old and timelessness ${ }^{42}$. This last aspect is one of Lao's strategies for re-contextualizing the griot's discourse, although not the only one. Not only does the young Senegalese adjust the beginning of his performance to the universe of discourse of his audience and emphasize the exoticism that is congenial to his show, but also the opening of Lao's performance (discourse 1), a topical moment in the African griot performance through which the "African audience" normally sweeps waiting for substantial contents, are unknown to the MEs' audience.

Moreover, the audience ignores the African history ${ }^{43}$. Therefore discourse 1 acquires a different significance in the MEs context for it is unheard of. Lao is aware of it ${ }^{44}$ and he evokes these contents to take advantage of the exotic appeal it has for his audience. In this way he increases in value as a griot and his (taking of) word is legitimized. Indeed, as we will see, Lao's "African griot" status, and his willingness to spread knowledge about "griottisme", become the very content of Lao's performances, as well as the main strategy of self-valorisation.

Discourse 2.

(2.1)

L: ... QUINDI POI TUTTI QUESTI imperi sono caduto e questi poi genti li usa in matrimonio come i griot adesso non è vicino al re però va a suonare nei matrimoni come anche l'altro giorno tu hai detto quando ho spiegato così poi il griot come ruolo nella società non è più re perché re non c'è però il griot sta in mezzo fra i popoli

G: fa il mediatore

L: mediatore come mediatore culturale+ecco+il griot poi fa questo perché il re non c'è era vicino re che trasmetteva e il re è caduto però sono qui con popolo sempre che dice quello che l'altro non non +quello che ha fatto però lo stesso tempo fanno+em+fanno e Da: (incomprensibile)

L: no fanno+ come si dice unire la gente+si io uno che ha bisogno di mia figlia per sposarla viene dal griot per dire che "vorrei che vai casa di Eleonora perché mio figlio ha visto sua figlia che vuole sposarla" e questo griot va con cola (...) perché noi da quando il regno è caduto+l'arte non è caduto+questo è importante perché il regno non c'è non deve essere storia però quello l'hanno portato fino adesso e penso che durerà un po' perché+anche noi come qua stanno toccando (incomprensibile) penso che dobbiamo conservare+anche questo +perché quella è la forza dell'Africa+l'Africa c'è 3,000 non lo so 3,000 quanto lingue+e altri paesi hanno colonizzato non ce l'hanno più loro lingua come esp come America del sud come Perù loro ce l'hanno solo spagnolo+\%Africa tutte lingua\%!tutte!+alcune tradizioni sono perse però alcune ancora c'è

[L: SO THEN ALL THESE empires came down and then peoples use them ${ }^{45}$ in marriage cause the griot is not near the king but he goes to play in marriages as you said the other day when I explained it / so then the griot is not the same social role near the king no more because there isn't the king no more but griot is in the midst of peoples

$\mathrm{G}$ : he is a moderator

L: a mediator as a cultural mediator / that's what I meant/ and then the griot does that because there isn't a king / he was near the king top transmit and the king came down but I'm always here with people to tell what the others don't/ the others have done but at the same time they ${ }^{46}$ do they do $\mathrm{Da}^{47}$ : (inaudible) 
L: no/ they do/ how do say / they tie people together/ yes / I / Someone who want to marry my daughter comes to say that "I want you ${ }^{48}$ to go to Eleonora because my son saw her daughter and he wants to marry her" and such griot goes with some kola (...) because since the kingdom came down we/ the art is not came down/ it's important because there isn't a kingdom (inaudible) / but they kept him ${ }^{49}$ until now and I think he will survive a while because / I think that we have to keep, too / we have to keep that / because that is the Africa force / In Africa there are 3,000 I don't know how many languages / and some other countries have been colonized and they don't have their language no more / as South America as Peru they have only Spanish/ Africa has all its languages! / All! / Some traditions are lost but some others are still there]

(2.2)

L: (...) adesso questo questo griot è finito e però il re è finito prima il griot rimane ancora+ +griot non è più vicino al re per fare il giornalismo però è nella società++si oggi marito $e$ moglie hanno dei problemìè il griot che porta il suo in strumento e suona+e lì fanno così e quando arriva fa così "non voglio sapere chi ha torto e chi non ha torto+oggi ho fatto sorpresa"++\%ecco\%+lì siede con suo instrumento+non non è (incomprensibile) griot non deve essere uno di famiglia++questo di famiglia come nonne nonni sono nati insieme + lui un giorno senti "ma sai che e Angela suo marito da un mese ci sono problemi non si parla" questo griot prende suo instrumento+va sorpresa+dice "sono venuto perché ho sentito c'è questo+ $e$ non ho bisogno chi+ha torto" dice e inizia a cantare+ e poi dice "vorrei che finite questa cosa" lui si alza lei si alza finisce così +e oggi questo è ruolo di griot quando matrimoni ...

[L: now such such griot is finished but the king is finished before and the griot keeps staying / the griot is not near the king to make journalism no more but he is in the society / today if a husband and a wife have some problems / it's the griot that brings his instrument and plays/ and there they do this way and when he arrives he says "I don't want to know who is wrong and who isn't / today I made you a surprise" / that's what I meant / there he sets down with his instrument / he he (inaudible) he can't be a family member (incomprehensible) / one day he hears "but you know that Angela and her husband have some problems and they refuse to talk since a month"/ such griot takes his instrument/ goes there by surprise and says "I've come because I heard that / and I don't need to know who is wrong / he says that and he starts singing" I'd like you to stop it "he stands up and she stands up and it finishes that way" / and today this is the role of griots when there is a marriage ...]

(2.3)

L: ... e l'altra volta ho spiegato adesso l'Africa il griot era sempre vicino al re+ il portavoce o quelque sorte giornalisti e adesso nes questi re caduti però il griot esiste++ho spie ho spiegato anche qual è il ruolo di griot nella società africana+il griot quando tuo figlio ha bisogno di figlia sono io che chiama+quando due persone litigano è griot che fa venire+unire questa cosa (...) sono i griot perché fanno animazione e questo è il lavoro di griot+quello si non c'è non è niente i genti tutti si+PERò lì viene hai capito fa alzare tutti EH+!ma quello è griottismo! l'Africa è così+il griot questo è il ruolo di griot cantare+em++come si dice portare:+la felicità dove c'è casino lui porta in strumenti suona e unisce le persone

(...)

El: e poi li invitano alle feste ai battesimi ai matrimoni

L: adesso adesso sì è così+adesso il griot è stato una cosa della cultura africana come hai detto matrimoni battesimi+ devi fare festa anniversario adesso anche

El: li invitano per

L: suonano sabar percussioni o kora o halam

[L: ... last time I explained you that in Africa griot was always near the king / he was the spokesperson or a kind of journalist and now these kings came down but the griot still exists/ I also explained which is the griot's role in the African society / the griot/ when you son need my daughter they call me / when two persons argue they ask me to come / (...) because griots do entertainment and this is the griot job 
/ that that ${ }^{50}$ is nothing (inaudible) / BUT he comes and everyone stands up EH! but that is griottisme! /this is Africa! / this is the role of griot he has to sing / how do you say / he has to take happiness where there is a mess / he takes instruments he plays and he ties people

El: and then they invite him to feasts to baptisms to marriages

L: now now yes it's like that / griot has been something of the African culture and now now he is like that as you said for marriages baptisms/ now he has to do the anniversary feast, too

El: and they invite him for

L: he plays saba percussions or kora or halam...]

Lao explains how the role of a griot has changed in African societies, by replacing it in a contemporary context and emphasizing its function of "social conflicts mediator": in this sense the griot is enhanced as "homme de parole". Even if such an emblematic figure of African societies is nowadays reactualised, Lao's discourse keeps on the "tradition side" playing on the effect this may have on the audience. In other words, "tradition" represents for Lao an element of continuity between the modern griot and the "kings' age", but most of all it is a strategy for inspiring an exoticism which is congenial to the show. Talking about kola and arranged marriages, about sabar and halam is not just describing a society: it is creating a fixed image of Africa, like a postcard, where griots solve social conflicts or manage social relationships with their "traditional instruments" and where words and music can settle a dispute between husband and wife. Such miseen-scène is represented also by direct speech, which dramatizes Lao's narration and the "mediator through words" role of griots. The frequent involvement of the audience by Lao is part of this dramatization. In other words, Lao establishes continuity between discourse 1 and 2 referring to an "art"-the "griottisme"-which is legitimated by History, but capable to stand the test of time by adapting to it. This is part of the very concept of "tradition" which is legitimated by History because it is History, and most of all it is years adding up to claim for its importance. Also, tradition has to be preserved ${ }^{51}$. Like languages belonging to a territory ${ }^{52}$, "griottisme" is a "tradition" which has to be kept. Claim for the role of griot, metalinguistic and (political) postcolonial discourse are blended in the same argumentation, which focuses on the importance of "the tradition".

In the third discourse, that is presented below, such "preservation of the tradition" finds a different discursive materialization. It crosses Lao's subjective experience and the process of meta-performative construction of his discourse. This third discourse, which I have named "Subjectification of the function of the griot", is particularly relevant in the perspective proposed in this article, as it is the one in which Lao truly focuses on himself. The term subjectification refers exactly to this: he assumes the role of the griot by describing more openly his performance within the MEs. Here is an example:

(3.1)

L: sì quello non puoi mai avere+ secondo me+non dico in generale, penso quello che io sai io dico sempre quello che ho preso eh (ride) e il caso non dice+ perché come che noi siamo cantastorie però io è diverso+ io mi nomina un griot moderno nomade perché non sono più in Africa quindi sono qua facendo quello che va con tempo+ non sono qui a suonare quello che è già suonato ogni (incomprensibile)+ no?capito? + io sto andando con il tempo adesso siamo questa generazione io suona quello che (incomprensibile) quella generazione P: (incomprensibile)

L: infatti+eh perciò mio distino solo mia creazione perché vorrei anche futuro troverà un stile che la kora $f a . .$.

[L: ... yes no one can ever have that/ in my opinion ... I do not say in general/ I think what I know/ I always say what I got eh (laughter) and the case does not say $53 / \mathrm{s}$ we 
are storytellers/but I'm different/ I call myself a modern travelling griot because I'm not in Africa I'm here doing what goes with the beat/ I'm not here to play what is already played (inaudible)/ no you know? I'm going with times/ we are now this generation and I play what (inaudible) this generation...

$\mathrm{P}^{54}$ : (inaudible)

L: yes/also in the future I want to try new styles for my kora] "griottisme" or, quoting Bakhtin, with the "interdiscourse of the griot's discourse" (thus following a cultural/family tradition through a process of identification), in discourse 3 what emerges is the specificity of his personal experience. He stands out from other griots, drawing the path that distinguishes him, a path marked by mobility ("[...] I'm different, I call myself a modern travelling griot because I'm not in Africa, I'm here, doing what goes with the beat, I'm not here to play what is already played"). This occurs through a self-designation process, in which Lao calls himself a "modern travelling griot", a self-exclusion process ${ }^{55}$ and through the differentiation of his discourse ${ }^{56}$. Rather than "modern" he describes himself as an "up-to-date griot", who knows how to adapt his art to real life. This self-valorization is therefore based on the contrast with other griots, thus on the comparison with the "tradition" introduced in discourses 1 and 2 (and not through the tradition). Modernity here is the ability to stand out, to make this art his own, to make it unique. This "self-exclusion process" is a distinguishing element of Lao's discourse and strongly depending on his history of migration. His discourse seems to focus on two aspects of himself: being an "unconventional" musician, inventor of a unique style, and being "an expatriated griot", who plays a role and a performance out of what Lao defines as its original context (the African "griottisme" tradition), exporting them to Europe.

This third type of discourse leads more clearly to considerations on the "metaperformative level" that underlies the language productions of the MEs: the "attention on the self" of Lao's discourse has a special significance for him, because he is an "homme de parole" (Camara 1976) but also because of his experience as a migrant. Concentrating on the significance that the word has for Lao and the way he relates to what he says, can tell us a lot on the importance of discursive productions in the understanding of social phenomena.

\section{Saying and Reflecting on the Saying: the Role of Meta- Performative Elements in Lao's Discourse}

Authier-Revuz's words below are appropriate for Lao's case, as his performance is full of meta-performative elements that are also the foundation of the espace de discours:

"Étudier la façon dont, dans les divers types de discours, fonctionnent les formes d'hétérogénéité montrée, c'est se donner accès à un aspect de la représentation que le locuteur y donne dans son énonciation, représentation qui traduit le mode de négociation avec l'hétérogénéité constitutive propre à ce discours".(Authier-Revuz 1982: 145)

"Saying" is for Lao not only a way to communicate to his audience but also a way to reason on himself and on the role of the word in the perception of himself. Likewise, it is a way to negotiate with his audience the replication of what he presents as a genre of discourse (the discourse griot) that is largely unknown to them. This is also confirmed by Urban (1996: 23) 57 $^{57}$ who considers "metadiscourse" as "a crucial link between discourse 
and the so-called social". This is why "the saying" becomes "the object" 58 : lingering over his utterance is for Lao both a discursive strategy and a way to justify and propose it to the audience. His discourse entangles in a spiral motion, which makes it both an instrument and a goal itself. The discourse becomes the object of the saying, and therefore an object of reflection. In Lao's case the reflection is on himself, on his work as a griot and a musician, as a performer in the MEs, but also as a migrant from Senegal ${ }^{59}$. The young man is not always aware of this process: the meta-performative level of his performance is heterogeneous, complex, and like all kinds of discourse, cannot be ascribed solely to his conscious activity. The speaker is not the sole author of his linguistic productions, which are instead negotiated and co-constructed with the other party and in relation to the context. The meta-performative activity, therefore, does not only depend on Lao's communication strategies, but also on the different interaction contexts of each MEs. In other words, the goal of this activity is not only to shape the performance and the role of the griot. This aspect is particularly relevant in the analysis of the MEs.

First of all a terminology note. The umbrella term "meta-performative" refers here generally to all those elements, linguistic but not only, that contribute to the construction and the reflection on Lao's performance in the context of the MEs. Among the meta-performative elements one can distinguish proper meta-performative components ${ }^{60}$, and meta-discursive as well as épilinguistiques ${ }^{61}$ components. The latter are especially interesting in the creation of Lao's narrative performance. They largely belong to what Authier-Revuz has first defined as modalisation autonymique ${ }^{62}$. On a formal level, Lao's discourse mainly includes the following elements:

- Foreign words or expressions (especially in French);

- Quotes;

- Self-corrections/adjustments;

- Direct speech;

- Considerations/resuming of the text in its materiality.

41 On a symbolic level some reflections on the text are also present (what L. Hébert and L. Guillemette (2009) define architextualit ${ }^{63}$ ). Particularly relevant is the role that such meta-performativity, especially the intralinguistics and symbolic ${ }^{64}$ reflection of the speaker on what he says, plays in the entextualization of a "ritual discourse" (Charaudeau \& Maingueneau 2002), as is "the griot's". In addition to that, the MEs performance is for Lao an opportunity to talk about migration in general, and in particular to give an account of himself as a migrant. For his audience, his presence and the espace de discours he has taken over are justified by his self-definition as a "modern travelling griot", i.e. by the role-and thus by the social and communication function-that he is playing in a new context (MEs). Also in this sense, then, Lao's performance represents a significant example of a mobility of discourse that goes along with that of individuals. Indeed, his discursive practice is a way of staging migration, himself and his experience of migration.

The following passage reveals the way Lao legitimizes himself and his discourse by relating his performance with the griot's activity and tradition ${ }^{65}$.

(3.2)

L: chissà+no solo questo sono io che immagino no nell'uomo+perché sono griot noi abbiamo (incomprensibile) facciamo camminare la testa e... è normale no... però non è per forza questo che ho pensato è questo che deve essere solo in mia... pensa così. Bien. Adesso vi 
suona la kora: sai che il griot parla e... e suona no?

(...)

L: e infatti vi devo spiegare anche kora perché non siamo in concerto però siamo in cena africana e sapere l'Africa anche se siete in Europa+ quindi + perché io suona in concerti magari poi puoi ascoltare e+la musica+come voi perché faccio tutte le stile eh+ quello va bene però oggi siamo qui parlare e spiegarvi suonare? no? secondo me è bene+?o volete che suona sempre sempre?

P: NO NO NO

L: ?parlare va bene no? quindi quando suoni anche viaggi quello che ho spiegato poi tu fa che immagina il re?capito? e rimani in Africa

[L: I wonder /maybe it's not only me supposing so ${ }^{66} /$ maybe because I am a griot and we let our mind wander and / it's normal isn't it? / but this is not necessarily so it could be only in my head/ I think so / good/ now I play the kora for you/ you know that the griot speaks and plays right?

(...)

L: actually I should explain you the kora as well / because we are not in a concert but in an African dinner and you have to know Africa even if you are in Europe / and then because I play in concerts / and maybe then you can listen to the music/ as you like it/ because/ hey I play all styles/ that' fine but we are here today to talk and explain the music? Aren't we? I think it's good or would you like me to play all the time?

$\mathrm{P}^{67}$ : NO NO NO

L: talking is good right? So when you play you also travel and what I explain you makes you imagine do you understand? And you are in Africa...].

If in the first part of this extract Lao explicitly presents himself as a griot, in the second part he asks the audience for the "permission" to take over that espace de discours, in order to negotiate and justify at the same time his narrative-descriptive performance. This justification takes place thanks to that "intermediary" position that Lao has decided to occupy: between Africa and Europe, between Africa and the African dinner, in between different styles (traditional and modern), between griot performance and concert, briefly, between "de-contextualization" and "re-contextualization" of his "griot's discourse".

This constant and explicit reference to his performance, in a self-reflective dialogue that involves the audience, allows him to negotiate his discourse with an audience who does not share the same universe of discourse. The re-contextualization of a "text"-as defined by R. Bauman and C. L. Briggs (1990)-like the "griot's discourse", may take place exactly in this crucial negotiation of the participants in a dialogue.

Lao's discursive productions in MEs are an interesting example of entextualization and therefore an evidence of the "interdiscursivity", which is the basic principle of any discourse. Lao's case represents a process of discourse's mobility that goes along with the mobility of individuals, with the social dynamics and roles. The re-contextualization strategies of a narrative performance-the griot's, as it is conceived and presented by Lao -in a new "espace de discours", as the one created in the evenings "stasera maffe" can tell us much about the processes of discursive as well as migratory circulation, and about their complexity.

There are two important aspects to be considered:

1. the process of construction of a performance and of an espace de discours;

2. the transposition of the role of the griot and of his discourse. 
former aspect is justified by the latter, in the same way the latter is allowed by the former. Both aspects are in fact involved in the tension between modernity and tradition-on which Lao bases his performances. They are both part and goal of the process of entextualization making Lao's performance so meaningful from the point of view of the discursive mobility. Interpreting Lao's case in terms of "putting migration into words" ("mise en discours de la migration")-which is the main topic of this special issue dedicated to "la prise aux mots de la migration"-has involved the analysis of the young man's construction, justification and management of an espace de discours (MEs), mainly trough meta-performative elements. Indeed, if Lao's discourse seems to aim at a selflegitimization before the audience-by imitating and referring to a "tradition" (the "griottisme") on the one hand and by highlighting the peculiarity of his experience on the other hand-the analysis proposed here tries to go beyond that. Through Lao's discourse, I have attempted firstly to highlight the migrant's and migration's spaces of action, and the social dynamics involved. Secondly, by emphasizing Lao's peculiarity and his ways of interpreting his migratory experience, I have tried to draw attention to the uniqueness of the itineraries that compose the migratory phenomenon, rather than attempting to homogenize them.

Lao's ways of (re)contextualize his "griot's discourse"-particularly on a metaperformative level-represent his very migratory process through different actions:

- acting as spokesperson of his own migratory experience;

- representing current ideologies about migration, Senegal, Africa...;

- constituting strategies of self-legitimation in a "new" context;

- representing power roles between interlocutors, i.e. between people taking part to "stasera maffe" evenings.

As R. Bauman and C. L. Briggs (1990: 68) illustrate, context "is not dictated by the social and the physical environment but emerges in negotiations between participants in social interactions" and the process of contextualization thus of entextualization of what Lao considers "the griot's discourse" consist just in that. His performance represents a "mise en discours" and an enactment of social changings: the process of discourse production is both a representation and an elaboration of social dynamics. So that what A. Duchêne (2009: 136) suggests about the role of discourse as a "locus de la fabrication de l'histoire et du changement" is pertinent, again. If we consider discursive productions as the place of materialization of "tout événement, toute expérience, tout souvenir", which are so socially accessible, we can catch complexity of discourse and, in the case analysed, of its processes of re-production. This means grasping the link between "historicité" (Duchêne 2009), discourse and language ideologies in political, economic and social transformations. This means considering the processes of discourse production as the place of representation and production of social dynamics and changes. 


\section{BIBLIOGRAPHY}

AUTHIER-REVUZ, J., 1982, Hétérogénéité montrée et hétérogénéité constitutive: éléments pour une approche de l'autre dans le discours, DRLAV 26: 91-151.

AUTHIER-REVUZ, J., 1995, Ces mots QUI ne vont pas de soi. Boucles réflexives et non-coïncidences du dire, 2 tomes (Paris: Larousse).

AUTHIER-REVUZ, J., 2007, “Arrêts sur mots. L'épreuve de la langue dans l'énonciation et l'écriture", in I. FENOGLIO (dir.), L'écriture et le souci de la langue: écrivains, linguistes; témoignages et traces manuscrites (Louvain-la-Neuve: Academia-Bruylant): 113-145.

AUTHIER-REVUZ, J., DOURY, M. \& REBOUL-TOURE, S. (DIR.), 2003, Parler des mots. Le fait autonymique en discours (Paris: Presses Sorbonne Nouvelle).

BАВСоск, В. А., 1980, "Reflexivity: Definitions and Discriminations", Semiotica 30: 1-14.

BAKHTIN, M., 1977, Marxisme et philosophie du langage (Paris: Éditions de Minuit).

BAUMAN, R. \& BRIGGS, C. L., 1990, "Poetics and Performance as Critical Perspectives on Language and Social Life", Annual Review of Anthropology 19: 59-88.

BLOMMAERT, J., 1999, Language Ideological Debates (Berlin-New York: Mouton de Gruyter).

BOURDIEU, P., 1977, “L'économie des échanges linguistiques”, Langue française 34: 17-34.

CAMARA, S., 1976, Gens de la parole: essai sur la condition et le rôle des griots dans la société malinké

(Paris-La Haye: Mouton).

CANUT, C., 2000, “Subjectivité et discours épilinguistiques”, Traverses 1: 27-52.

CANUT, C., 2007, Une langue sans qualité (Montpellier: Lambert-Lucas).

CANUT, C., 2008, Le spectre identitaire. Entre langue et pouvoir au Mali (Montpellier: Lambert-Lucas).

CHARAUdEAU, P. \& MAINGUENEAU, D. (DIR.), 2002, Dictionnaire d'analyse du discours (Paris: Éditions du Seuil).

DIOP, C. A., 1979, Nations nègres et culture (Paris: Présence Africaine).

DUCHÊNE, A., 2009, "Discours, changement social et idéologies langagières”, in D. AQUINO-WEBER ET AL. (dir.), Sociolinguistique historique du domaine gallo-romain. Enjeux et méthodologies (Berne-New York: Peter Lang): 131-150.

HÉBERT, L. \& GUILLEMETTE, L. (DIR.), 2009, Intertextualité, interdiscursivité et intermédialité (Laval: Les Presses de l'Université de Laval).

LEVELT, W. J. M., 1989, Speaking: From Intention to Articulation (Cambridge-Massachusetts: The MIT Press).

PIZzolAto, G., 2012, La parole migrante: pratiche e ideologie linguistiche di migranti senegalesi tra Senegal e Italia, Phd Thesis (Torino: Università degli Studi di Torino; Paris: Université Paris Descartes).

SILVERSTEIN, M. \& URBAN, G. (EDS.), 1996, Natural Histories of Discourse (Chicago-London: The University of Chicago Press). 
TARRIUS, A., 2002, La mondialisation par le bas. Les nouveaux nomades de l'économie souterraine (Paris: Balland).

URBAN, G., 1996, “Entextualization, Replication and Power”, in M. SILVERSTEIN \& G. URBAN (eds.), Natural Histories of Discourse (Chicago-London: The University of Chicago Press).

\section{NOTES}

1. "Decentering and recontextualization have powerful implications for the conduct of social life, investigating how this process takes place and how individuals gain rights to particular modes of transforming speech can therefore illuminate issues of central concern to anthropologists, linguists, folklorists, and literary scholars" (BAUMAN \& BRIGGS 1990: 61).

2. For more details see PIZzolato (2012).

3. That is to say that such language productions are not just the words of an individual, rather they are the performance of a professional (a griot).

4. "Maafe tonight!"

5. Henceforth MEs.

6. Indeed Lao is known in Turin as a musician, especially because of his concerts.

7. "If a given instance of discourse is unique by virtue of its formal properties, as well as the infinitely rich specificity of the context in which it is embedded, by definition it cannot be reproduced. Replication, however is an attempt at reproduction, at relocating the original instance of discourse to a new context-carrying over something from the earlier to the later one" (URBAN 1996: 21).

8. Searching for legitimization through an established tradition in West Africa (the "griottisme").

9. SILVERSTEIN \& URBAN (1996: 5-6) words are very clear in this sense: “Texts generate their publics, publics generate their texts, and the analysis of 'meanings' now has to take into account a historiography of the context of production, the mechanisms and instruments of reproduction and receptions, ways of storage and remembering. The fact that discourse, texts, talk all have their 'natural history'-a chronological and sociocultural anchoring which produces meaning and social effects in ways that cannot be reduced to text-characteristics alone. Context, in this approach is historical and the dynamics of textualization is not restricted to the event in which discourse is produced and exchanged. Every event-dynamic and processual in itself-is situated as a part of a tradition of events, and this tradition contributes heavily to what happens in each concrete event."

10. As URBAN (1996: 21) suggests: "One aspect of natural history of the discourse is the process of replication."

11. See В. А. ВАВСОСК (1980).

12. This is not a merely descriptive conception; it changes the perspective on the relations between places, people and symbolic systems (like language). Separating language from its "territory" and considering it as a language performance means to deterritorialize discourse and assign it to a three-dimensional depth. Considering the latter as an interconnected and interconnecting space (dialogism), amplifies its symbolic 
meanings. It increases its potential representations for the interpretation of reality. Through interdiscursivity, we can grasp the complexity of the migration processes, by understanding the interpenetration, the overlapping, and mutual influence of processes and practices that exist and are produced in the interconnected spaces of reality. The discourses of individuals represent the complexity and contradictory nature of migration: migrating boosts circulation of discourse and of the imageries that come with it, as it merges and blends them. The principle of interdiscursivity also makes the relationship between the migrant and the site symbolic. Firstly it prevails over the concepts of "here" and "there", and defeats the schematic polarization of the migration phenomenon between "country of origin" and "host country", between "before" and "after", it also enhances individual paths and social networks. Taking into consideration the discourses of migrants also questions the idea of migration itself by eluding territorialization, the predominance of push pull laws, of purely economic factors, and therefore considering migration under the aspect of the (subjective) discourse of the migrant, which may provide new insights.

13. In the terms Lao defines it, as we will see.

14. Lao is a musician, composer and songwriter.

15. The maafe (or mafé, maffé, maffe) is a Western African dish-common in Senegal-made from rice, meat, vegetables and peanut sauce.

16. Lao narrated a few accounts of African history-often referring to the migration reality-news accounts from Senegal or regarding his personal experience. He also described the musical instruments he was playing or aspects of his artistic activity.

17. Approximately 5 to 15 people. They were often friends or acquaintances of the couple, who had become familiar with MEs through Eleonora and Lao or through friends in common. Every MEs evening was arranged by the couple in agreement with the guests, i.e. they would decide the date and time of the appointment and the cost of the dinner at the guests' disposal. They also agreed on the amount of people invited so that the organizers could predispose their house. The guests didn't have any other information about the event: as the couple explained to them, they would participate to a "Senegalese dinner" followed by a "traditional musical show" performed by Lao. Therefore people invited to the different MEs shared the curiosity for an "exotic event" and the acquaintance with the couple (if not a real affection as it was often the case), other than that the audience was heterogeneous and different every time.

18. This aspect is inherent in the concept of exoticism.

19. The alternation between pieces from the traditional griot repertoire of the mande area and other original ones, a mix of songs of different inspirational sources.

20. Furniture, layout of the room, food...

21. The times and the history Lao talks about give relevance to the social role of the griot, which otherwise would not be easily recognized by an Italian audience.

22. "Senegal of Italy", the Italian context and, in general, the European one, but not only, as we are going to see.

23. "Entextualization may well incorporate aspects of context, such that the resultant text carries elements of its history of use within it" (BAUMAN \& BRIGGS 1990: 73). 
24. For example, introducing himself as Kouyate-the name of one of the better-known griot families-would have prompted an aware audience about the griot tradition of his area of origin whereas it did not produce any reaction in this audience.

25. As Maingueneau (CHARAUdeAU \& MAINGUENEAU 2002: 507) argues, citing Charaudeau: "Chauraudeau voit dans un rituel socio-langagier 'l'ensemble de contraintes qui codifient les pratiques socio-langagières et qui résultent des conditions de production et d'interprétation (circonstances de discours) de l'acte de langage"', which implies assigning and interpreting those roles.

26. Transcription rules:

\begin{tabular}{|l|l|}
\hline ?how are you? & question \\
\hline !word! & emphasis \\
\hline WORD & high volume \\
\hline \%word\% & low volume \\
\hline$(.)$. & omission \\
\hline+ & pause \\
\hline
\end{tabular}

27. During the fieldwork Lao had difficulty in speaking Italian, on a grammatical as well as on a lexical level. I opt for a literal translation of his speech in order to render it as likely as possible and to avoid to speak "on Lao's behalf" (since often it is not easy to interpret his words).

28. Audience.

29. Eleonora, Lao's wife.

30. Audience.

31. Musical genres.

32. The kora is a traditional 21-string harp-lute used in West Africa.

33. In this passage it is very difficult to understand what "castle" refers to.

34. Audience.

35. My grandfather kept the balafon with an harm.

36. Lao's surname.

37. L: "(he) handed down from generation to generation".

38. L: "the griot is always near the king", "there is always the griot that has to promote the king".

39. For more details see DIOP (1979). CANUT (2008: 176), commenting on Diop, writes: “[...] alors que l'Occident est décadent, pessimiste, dévasté par la haine et les guerres, l'Afrique est un berceau de paix, optimiste, promesse d'un nouvel humanisme, qui permettra la régénérescence de la civilisation occidentale, chargée de trop de raison et pas assez d'émotion. L'Afrique de l'âge d'or n'est pas loin. La raison en est simple: l'Afrique possède une culture, une civilisation, une essence, une âme, qui ne découle pas de l'histoire, mais qui est là depuis toujours, hors histoire, dans son unicité et prend sa 
source de l'Égypte. Ainsi le nègre typifié prend naissance dans un substrat naturel, culturel et ethnique homogène, Diop ne revient donc pas à des sources authentiques, il les crée pour l'Afrique entière."

40. L: "The first instrument of griot", "they are communication instruments before telephone", "these instruments were born in the Mande empire" "the first men/they are really powerful good heavens!"

41. L: "at those times there wasn't written tradition in Africa", "at these times we, the Kouyates, we were journalists but not written journalists but spoken ones and we were also dancing because they dance".

42. L: "at those times", "many many years", "génération à génération", "at first times, before written tradition", "imagine how many centuries before Italy they were born".

43. As demonstrated by the frequent questions of the audience to Lao, interrupting the show.

44. And he becomes aware of it throughout the course of different MEs.

45. Griots.

46. Griots.

47. Audience.

48. The griot.

49. The griot and his role.

50. Lao is claiming that this "modern" function of today's griot is worthless.

51. "L: I think that we have to keep, too / we have to keep that / because that is the Africa force".

52. "L: in Africa there are 3,000 I don't know how many languages".

53. The passage is difficult to interpret.

54. Audience.

55. Most of the time during my fieldwork Lao would try to "stand-out" from the others: other griots, other migrants, other Senegaleses, etc. cutting himself off from any kind of "identification".

56. Extensive use of first-person singular and plenty of adversative words to distinguish him from "the other griots".

57. "Linkage of the social to the discursive can only be made through the metadiscursive, and the metadiscourse forms part of the circulating discourse [...]. I hope to show that there is a correlation between the social relationships and discourse relationships that is simultaneously a correlation between discourse relationships and metadiscursive characterizations" (URBAN 1996: 23).

58. "Dans tout fait de réflexivité autonymique il y a un signe qui s'impose comme objet, propulsé sur le devant de la scène comme 'personnage' auquel le dire fait référence, sortant par là de son rôle de rouage ordinaire de la machinerie du dire, voué à l'effacement dans l'accomplissement de sa fonction ordinaire de médiation" (AUTHIER-R EVUZ 2003: 71).

59. AUTHIER-REVUZ (2007: 122) writes: “[...] est en jeu une même matérialité de la langue et un même enjeu subjectif essentiel, la manière singulière pour un sujet, qui est sujet d'être parlant, de se 'poser', par son dire, dans le langage." 
60. Mainly explicit references to the audience, to bring them in the show.

61. I preferred not to use the label "metalinguistic", as this refers more appropriately to linguists' self-reflective activity, according to CANUT (2000).

62. For more details on the notion of "modalisation autonymique", refer to AUTHIER-REVUZ (1995).

63. “Un texte-occurence renvoie à son type (ou à ses types), c'est-à-dire à son genre (par exemple le roman d'aventure) ou, plus généralement, au discours dont il relève (par exemple, la littérature) ou à ce qui constitue 'l'essence' de ce discours (par exemple, la littéralité). Dans son sens large, cette relation peut également recouvrir les renvois à un type dont ne relève pas l'occurrence" (HÉBERT \& GUILLEMETTE 2009: 3).

64. The function of the "word" and specifically the function the event MEs has for him, as an opportunity to put into practice his role as a "modern griot".

65. Sometimes following this tradition, sometimes in opposition to it.

66. Lao has just forecasted African economic future with respect to the European one, theorizing a reversal of power hierarchies between the two continents.

67. Audience.

\section{ABSTRACTS}

The notion of "entextualization" proposed by R. Bauman and C. L. Briggs (1990) can be used, from a linguistic anthropology perspective, as a means of interpreting the processes of migratory circulation through the analysis of linguistic productions of migrant subjects. Drawing upon the musical-narrative performance of a young griot coming from the Casamance region and living in Italy, the article examines the discursive and metaperformative strategies of "decentering" and replacing an allegedly "griot's discourse" in a different context he performs. The tension between a process of essentialization of "the griottisme tradition" on the one hand, and the subjectification of the migratory experience through performance on the other hand, highlights the importance of taking into account the ideological aspects of the linguistic productions, in analyzing and interpreting social dynamics.

Dans une optique d'anthropologie du langage, la notion d'« entextualization» proposée par R. Bauman et C. L. Briggs (1990) est utilisée pour tenter d'interpréter les processus de circulation migratoire à partir des productions discursives des sujets migrants. La description des performances narratives et musicales d'un griot casamançais migrant en Italie sert à l'analyse des stratégies discursives et métaperformatives mises en place par ce jeune Sénégalais pour la décontextualisation et la re-contextualisation d'un « discours griot » prédéterminé. La tension entre le processus d'essentialisation de "la tradition du griottisme» d'une part et le processus de subjectivation de l'expérience migratoire de l'autre met en évidence l'importance des éléments idéologiques dans l'analyse des productions langagières pour l'interprétation des dynamiques sociales. 
INDEX

Keywords: Dialogism, Discourse Production Process, Entextualization, Essentialization, Migratory Circulation, Tradition

Mots-clés: dialogisme, processus de production du discours, entextualisation, essentialisation, griot, circulation migratoire, tradition

\section{AUTHOR}

GIULIA PIZZOLATO

CePeD, Université Paris Descartes, Paris. 